\title{
Trabalhonecessário
}

ISSN: 1808 - 799X

ANO 12, № 19 - 2014

\section{AUTOGESTÃO: MARCA INDELÉVEL NO PENSAMENTO DE ROSA LUXEMBURGO}

\author{
Everton Werneck de Almeida ${ }^{1}$
}

\section{RESUMO}

O presente ensaio tem enquanto objeto de análise 0 pensamento da revolucionária alemã Rosa Luxemburgo, ou, mais precisamente, a forma como o tema da autogestão é abordado no mesmo. Ao fim e ao cabo, chega-se a conclusão que a autogestão social, uma das mais antigas e principais aspirações do movimento operário, perpassa todo o seu pensamento: contrapondo-se tanto ao reformismo socialdemocrata quanto ao projeto de socialismo que então se constituía na Rússia leninista, o pensamento de Rosa Luxemburgo apontará a todo momento para a indispensabilidade do protagonismo das massas operárias no processo de construção da nova sociedade socialista.

PALAVRAS- CHAVE : Autogestão-Rosa Luxemburgo-Socialismo

\section{ABSTRACT}

This article has as an object of analysis the thought of the German revolutionary Rosa Luxemburg, or, more precisely, how the theme of self-management is approached in the same. After all, one reaches the conclusion that the social ownership, one of the oldest and main aspirations of the labor movement pervades all his thought: in contrast to both the social democratic reformism as the design of socialism which then constituted the Leninist Russia, the thought of Rosa Luxemburg will point all the time for the indispensability of the role of the working masses in the process of building a new socialist society.

KEYWORDS : Self-management-Luxemburg- Socialism

\footnotetext{
1 Graduado em ciências sociais pela Universidade Federal Fluminense; Mestre em serviço social pela Universidade do Estado do Rio de Janeiro (UERJ); Professor de sociologia no ensino médio da rede estadual de educação do Rio de Janeiro. E-mail: evertonwerneck@ig.com.br
} 


\section{Trabalhonecessário}

ISSN: 1808 - 799X

ANO 12, № 19 - 2014

\section{Introdução}

Segundo Bourdet e Guillerm, o termo "autogestão" passou a ser empregado somente nos anos 1950, muito embora variadas ideias e práticas de coletivização e democracia no trabalho fossem disseminadas desde o século XIX (NAHAS, 2011). Todavia, o que viria a ser autogestão?

O contato com a literatura produzida sobre o tema permitiu que nos deparássemos com certa variedade de experiências concretas que, indistintamente, se atribuíam a definição de "autogestionárias". Sobre isso, Bourdet e Guillerm (1976) alertavam para o emprego "indiscriminado" do termo em questão, configurando quase uma "moda" 2 .

Assim, adotamos a designação mínima de autogestão como sendo: organização onde o poder de decisão dos assuntos coletivos caberia aos seus próprios integrantes, inexistindo um corpo separado de funcionários especializados na gestão dos assuntos coletivos.

Por outro lado, é importante demarcar de imediato o seguinte: a intrínseca ligação da proposta autogestionária com o movimento operário e os ideais socialistas. Ou seja, a autogestão emerge e se dissemina no pensamento e militância no contexto da tradição operária e socialista.

A pista para compreender porque o capitalismo surge como terreno mais fértil para o florescimento de ideias autogestionárias, quem fornece é Marx (1982), quando ressalta o papel progressista cumprido pelo sistema do capital no que diz respeito ao desenvolvimento das forças produtivas.

Sim, o capitalismo alavanca a produção de riquezas, impulsiona o progresso científico e tecnológico. Mas de que maneira? A dinâmica do capital, cuja consequência Marx enfatizou, reside na busca pela crescente valorização do

\footnotetext{
2 Algo sobre isto, Kosik (1976) já havia posto, quando afirma que, em dado conhecimento produzido sobre a realidade, quando disseminado ou socializado pelo conhecimento comum, tem, muitas das vezes, seu sentido original modificado, sofrendo uma espécie de "vulgarização natural".
} 


\section{Trabalhonecessário}

ISSN: 1808 - 799X

ANO 12, № 19 - 2014

capital investido, com a extração de mais-valia do operariado. $O$ burguês possui duas formas de fazer o trabalhador produzir mais, ganhando o mesmo ou menos em salário. Através da simples extensão da jornada sem pagamento adicional (a mais-valia absoluta) ou por intermédio da introdução de máquinas, tecnologias e formas de organização do trabalho voltadas para a intensificação do trabalho e consequente incremento da produtividade do empregado. Assim ele produz mais dentro da mesma jornada de trabalho paga pelo capitalista (a mais-valia relativa).

É dentro desse contexto, marcado pela concorrência por mercados, que o capitalista se moverá em busca do constante aumento de sua produtividade. Para isto, lança mão do aprofundamento da divisão do trabalho, da introdução de maquinários e de novas tecnologias, dentre outras medidas. $E$ isso se realiza por meio da heterogestão que intensifica e estende essa disciplina sobre amplos contingentes de trabalhadores.

Braverman (1977), por meio de relato histórico, mostra como o trabalhador vai, progressivamente, perdendo o controle sobre o processo produtivo, vendo a sua participação no trabalho ser cada vez mais reduzida a gestos simples e repetitivos; debruçado sobre máquinas e tecnologias; vigiado e comandado por outrem ${ }^{3}$.

Junto a esse processo de "degradação do trabalho", caminha a tendência à destruição ou subsunção de modos de produção antigos ao novo modo de produção hegemônico (Marx, 1977). Ao lado do livre jogo da concorrência, que arruína pequenos proprietários em geral, "atirando-os às fileiras do proletariado"4, originando, assim, novas levas de trabalhadores explorados, não somente em ter-

\footnotetext{
${ }^{3}$ Pari passu a esse processo de "degradação do trabalho", segundo Braverman (1977), avança a criação de hierarquias e postos de supervisão no interior da indústria com o objetivo de controlar a produtividade de cada operário.

4 Isso também já se encontra presente em O Manifesto Comunista, quando Marx e Engels abordam a questão da pequena burquesia, que supostamente estaria, sob o capitalismo, fadada a desaparecer: caso fosse vitoriosa no jogo da livre-concorrência, cresceria e tornar-se-ia integrante da "grande burguesia", caso
} 


\section{Trabalhonecessário}

ISSN: 1808 - 799X

ANO 12, № 19 - 2014

mos de propriedade quanto com relação aos saberes e domínio sobre seu próprio trabalho.

A intensificação e a extensão da heterogestão são meios típicos da realização capitalista. A heterogestão decorre e reproduz a expropriação, na medida em que o trabalhador não detendo a propriedade dos frutos de seu trabalho, não tem o controle sobre seu próprio trabalho, sendo comandado "de fora", pelo capitalista e por sua burocracia. Assim sendo, sob o processo de valorização do capital, desenvolvem-se as forças produtivas, ao mesmo tempo em que se aprofunda a heterogestão e a alienação do trabalho (MÉSZÁROS, 2006).

Todavia, como atesta a história, este proletariado, forjado pelo próprio capital, não permaneceria longo tempo sem esboçar qualquer reação ou resistência perante a exploração, a pobreza, as desigualdades, o autoritarismo e a alienação. Cedo ou tarde, aquele se poria em luta contra o capital e seus representantes, "fazendo girar a roda da história".

Tanto Quintaneiros (2002) quanto Hobsbawm (2005) demonstram que o movimento operário acompanhou de perto, sobretudo ao longo do século XIX, o desenvolvimento das relações de produção burguesas. Primeiramente, os operários reúnem-se para lutar coletivamente por melhores salários, melhores condições de trabalho, redução da jornada, dentre outras reivindicações. Aquilo que Lênin denominou de luta "economicista", "espontânea", levada a cabo pelas organizações sindicais constituídas pelos próprios operários para defender seus interesses ${ }^{5}$. No bojo das reivindicações dos trabalhadores figura a autogestão como forma de superação da alienação completa imposta pelo capitalismo. Afinal, 


\section{Trabalhonecessário}

ISSN: 1808 - 799X

ANO 12, № 19 - 2014

essas reivindicações econômicas e a democratização no trabalho, com o passar do tempo, mostraram-se impossíveis de serem completamente contempladas nos limites do modo de produção burguês, com sua necessária hierarquização, controle e autoritarismo no processo produtivo ${ }^{6}$.

Portanto, o que foi sendo evidenciado na história é que a autogestão de forma alguma seria obtida fora da completa socialização dos meios de produção, ou seja, do socialismo ${ }^{7}$.

Para sermos consequentes, teoricamente coerentes e fiéis à história, devemos afirmar que a luta pela autogestão insere-se, sem meio termo, nas lutas do movimento operário pelo socialismo. Mas, as lutas pelo socialismo passariam, necessariamente, pela autogestão?

Para grande parte das correntes político-ideológicas, não se poderia falar em socialismo sem falar de autogestão. Porém, não foram tais vertentes ideológicas que conseguiram hegemonizar o movimento operário ao longo da história, desde o século XIX até o século XX. Os estudos realizados por Bihr (2010) sublinham que a hegemonia política e ideológica sobre o movimento operário, no período citado, pertenceu à vertente comunista (marxistas ortodoxos ou marxista-leninistas) e à corrente socialdemocrata (reformista).

Mais do que grandes e significativas experiências históricas concretas, a autogestão é uma aspiração que vem acompanhando o desenvolvimento do mo-

5 Offe (1995), por exemplo, vai denominá-las de "coalizão de vendedores de força de trabalho", compreendendo que a ação coletiva em torno de melhores remunerações seria algo, senão natural, ao menos esperado numa economia de mercado.

${ }^{6}$ Burawoy (1990), para citar mais um destacado autor, afirma que, quanto maior o despotismo fabril, menor a rede de seguridade social a proteger o trabalhador de uma dada sociedade e, ao contrário, a maior quantidade e qualidade das políticas sociais de um dado país contribuiria para reduzir o autoritarismo do capital e seus representantes no âmbito do processo produtivo propriamente dito.

7 À semelhança do ocorrido com o conceito de autogestão, também "socialismo" foi apropriado das mais distintas formas por variadas correntes políticas. Entretanto, crê-se que a questão da mudança da propriedade dos meios de produção deva ser essencial para poder falar-se em "socialismo". 


\section{Trabalhonecessário}

ISSN: 1808 - 799X

ANO 12, № 19 - 2014

vimento operário já desde o século XIX. Constitui, até hoje, um projeto de emancipação plena da classe trabalhadora, ainda não realizado.

A perspectiva de análise aqui empregada é fundamentalmente histórica, pois parte-se do princípio de que o pensamento autogestionário se vincula às transformações, mutações e realinhamentos do modo de produção capitalista. A produção de idéias (dentre elas as da autogestão) tem, necessariamente, origem nas condições materiais de existência. As idéias ou as teorias não são desafiliadas (ou a - históricas), mas elas existem em consonância com a sociedade e suas contradições.

Ao longo de toda a sua vida e obra, Karl Marx sempre sustentou que as ideias, em suas origens e fundamentos, necessariamente nascem a partir de determinadas condições materiais de existência. Desse modo, Marx nunca deixou de lançar severas críticas sobre uma grande variedade de concepções de mundo, por ele consideradas "idealistas", que atribuíam a certas teorias, ideologias ou modos de pensar o estatuto de a-históricas, "naturais", que existiriam por si só, sem quaisquer ligações com as condições econômicas, sociais e políticas de uma determinada época.

Nestes termos, Rosa Luxemburgo foi uma apaixonada militante revolucionária, dedicando toda uma vida à causa do socialismo e da emancipação da classe trabalhadora. Acreditamos que sua trajetória política, seu ativismo social, enfim, sua práxis concreta, se expressava diretamente em suas produções teóricas. As ideias acerca da autogestão eram pensadas em sintonia com as necessidades das lutas quotidianas, dos conflitos políticos de sua sociedade, nos quais tomava parte ativamente, sempre almejando o socialismo e a verdadeira emancipação da classe operária (LOUREIRO, 1995). 


\section{Trabalhonecessário}

ISSN: 1808 - 799X

ANO 12, № 19 - 2014

Em vida, Luxemburgo destacou-se, inicialmente, na militância do Partido Socialdemocrata Alemão, ao longo das primeiras décadas do século $\mathrm{XX}^{8}$. A consulta ao conjunto de suas obras permitiu-nos perceber que Luxemburgo constrói sua visão do socialismo e da autogestão no calor do debate com as vertentes reformista e bolchevista, esta última mundialmente em evidência ao tomarem a liderança do processo revolucionário russo, em 1917. Aquelas primeiras décadas dos anos 1900 constituíram o cenário de uma acirrada disputa pela hegemonia no seio do movimento operário que, de acordo com Bihr (2010), perduraria até a crise capitalista dos anos de $1970{ }^{9}$.

No ano de 1918, junto com outros camaradas, Luxemburgo funda o Partido Comunista Alemão, abandonando o antigo Partido Socialdemocrata, que, àquela altura, já houvera enveredado pelos caminhos do reformismo e do revisionismo ${ }^{10}$. Durante grande parte do tempo, Luxemburgo percebe o crescimento de tal tendência conservadora no interior do partido e do movimento operário como um todo e passa a dialogar com tal facção política no decorrer de seus trabalhos.

Sem embargo, seriam estes os pressupostos teórico-conceituais que orientaram o estudo que realizamos sobre a autogestão no pensamento de Rosa Luxemburgo.

\footnotetext{
${ }^{8}$ A esta altura, o Partido Socialdemocrata Alemão era o grande inspirador da esquerda, o modelo a ser seguido pelos partidos socialdemocratas de todo o mundo. Tragtenberg (1989) assinalou que servia de modelo no seio da II Internacional. Assim como, mais tarde, o Partido Comunista Russo serviria de inspiração para o restante, no interior da III Internacional.

9 Em sua obra mais famosa, "Reforma ou Revolução?", Rosa Luxemburgo dialoga diretamente com as concepções reformistas que começavam a adquirir força no movimento operário. Em "A Revolução russa", dialoga desta vez com os bolcheviques então vitoriosos na Rússia. Em "Greve de massas, partidos e sindicatos", reflete sobre a conjuntura revolucionária russa de 1905 e dialoga com ambas as correntes, então presentes no movimento operário, bolcheviques e reformistas.

10 O estopim para que Luxemburgo e demais militantes revolucionários se afastassem de vez da socialdemocracia fora o apoio desta à Primeira Grande Guerra Imperialista, o que significava uma traição aos princípios internacionalistas e classistas. A socialdemocracia passara a apoiar seus respectivos Estados e burguesias numa guerra pelos interesses dos últimos e não dos trabalhadores. (TRAGTENBERG, 1989)
} 


\section{Trabalhonecessário}

ISSN: 1808 - 799X

ANO 12, № 19 - 2014

\section{1- Como alcançar a nova ordem socialista? A resposta de Rosa Luxemburgo.}

As propostas de passagem lenta e gradual ao socialismo através de reformas pontuais na sociedade capitalista - com ampliação de direitos políticos e sociais para a classe operária eram frequentemente criticados por ela. A luta eleitoral e parlamentar, enquanto principal estratégia para as reformas, chocavam-se também com os seus ideais socialistas e revolucionários, na medida em que tais teses teriam como consequência não a construção do socialismo, mas, sim, a manutenção do capitalismo e todas as suas iniquidades e contradições.

A primeira vista, o título deste livro pode parecer surpreendente. Reforma social ou revolução [...] Para a socialdemocracia lutar dia a dia, no interior do próprio sistema existente, pelas reformas, pela melhoria da situação dos trabalhadores, pelas instituições democráticas, é o único processo de iniciar a luta da classe proletária e de se orientar para o seu objetivo final, quer dizer: trabalhar para conquistar o poder político e abolir o sistema salarial [...] a luta pela reforma social é o meio, a revolução social o fim [...] Esses dois elementos fulcrais do movimento operário encontramo-los opostos, pela primeira vez, nas teses de Eduard Bernstein [...]. Na controvérsia entre Bernstein e os seus partidários, o que está em jogo- e no partido cada um deve ter consciência disso- não é este ou aquele método de luta, nem o emprego desta ou aquela tática mas a própria existência do movimento socialista. (LUXEMBURGO, [1900] 2012, p.1)

Luxemburgo ([1900], 2012), ao debater criticamente os postulados reformistas, realiza uma defesa intransigente da via revolucionária para 0 socialismo. Demonstra as incoerências e contradições do reformismo que, a seu ver, de forma alguma seria capaz de alcançar o socialismo.

A corrente reformista defendia a tese de que o capitalismo de então havia "se adaptado". Mas na verdade, o que fez foi criar mecanismos e alternativas que 


\title{
Trabalhonecessário
}

ISSN: 1808 - 799X

ANO 12, № 19 - 2014

atenuariam suas crises e contradições internas. Nesse quadro, os reformistas abandonaram a crítica radical que localiza nas próprias contradições do modo de produção capitalista a origem e a necessidade histórica do socialismo.

\begin{abstract}
Ainda na opinião de Bernstein, a capacidade de adaptação do capitalismo manifesta-se primeiro no fato de já não existir crise generalizada, o que se deve à evolução do crédito das organizações patronais, das comunicações e dos serviços de informação; segundo, na tenaz sobrevivência das classes médias, resultado da diferenciação crescente dos ramos da produção e da elevação de largas camadas do proletariado ao nível das classes médias; terceiro finalmente, melhoria econômica e política do proletariado, através da ação sindical. (LUXEMBURGO, [1900], 2012, p.2).
\end{abstract}

O que se vê é que a corrente reformista calcava suas teorias numa situação meramente conjuntural, consubstanciada em melhorias dos rendimentos, das condições de trabalho e mais direitos políticos e sociais (MARSHALL, 1968).

Havia sim, conforme descrito anteriormente, um movimento em direção a melhorias da situação de parte do proletariado nas principais nações capitalistas da Europa ainda que a custas da superexploração de outros trabalhadores. A viragem reformista da socialdemocracia que então se dá, nada mais significava do que a expressão político-teórico da nova situação de setores da classe trabalhadora, como a chamada "aristocracia operária". As políticas fordistas de premiações e pagamentos por produtividade, mais a conquista de uma série de direitos políticos e sociais, deram origem a estratos ou frações da classe operária melhor remuneradas. Mais qualificados e gozando de maior prestígio do que o restante da classe trabalhadora, vimos emergir a chamada "aristocracia operária". Hobsbawm (2000) já havia notado indícios do surgimento da referida fração da classe operária na Inglaterra do século XIX, observando, desde então, a sua progressiva expansão até as décadas iniciais do século seguinte ${ }^{11}$. 


\section{Trabalhonecessário}

ISSN: 1808 - 799X

ANO 12, № 19 - 2014

Os estudos de Lênin ([1916], 2001) apontavam para a constituição de uma aristocracia operária, principalmente nos países centrais, enquanto fruto da sobrexploração levadas a cabo em países da periferia do sistema. Essas áreas coloniais, da qual poderiam auferir superlucros, sustentariam a formação dessa "aristocracia do trabalho"12. Assemelhando-se à linha de interpretação seguida por Lênin ([1916], 2001), Leon Trotsky, em "A revolução traída"(1937), percebe a formação de uma aristocracia operária também na URSS (União das Repúblicas Socialistas Soviéticas), destacando o papel cumprido por esse estrato da classe trabalhadora enquanto ponto de apoio e sustentação da burocracia.

Em meio aos argumentos e críticas lançados por Luxemburgo ([1900], 2012) contra as teses reformistas, uma, em especial, vale a pena abordarmos de forma um tanto quanto mais detida. Trata-se da crítica ao cooperativismo enquanto estratégia para a realização do socialismo.

Segundo Luxemburgo ([1900], 2012), o reformismo entendia a disseminação de cooperativas como sendo um dos caminhos para a progressiva socialização da economia. Ainda segundo Luxemburgo ([1900], 2012), no capitalismo a circulação acaba dominando a produção. O cooperativismo, embora almejasse transformações no processo produtivo capitalista, logo sucumbiria às

\footnotetext{
${ }^{11}$ Assim Hobsbawm definiu a aristocracia operária: "Não há nenhum critério único, simples, de participação na aristocracia do trabalho. Pelo menos seis fatores diferentes devem, teoricamente, ser considerados. Primeiro, o nível e a regularidade dos ganhos do trabalhador; segundo, suas perspectivas de seguridade social; terceiro, suas condições de trabalho, inclusive a maneira como ele foi tratado pelos capatazes e patrões; quarto, suas relações com a camada social abaixo dela; quinto, suas condições gerais de vida; finalmente, suas perspectivas de progresso futuro $e$ as dos seus filhos. Destes o primeiro é incomparavelmente mais importante..." (HOBSBAWM, 2000,p.320).

12 Lênin ([1916], 2001) vislumbra a possibilidade de surgimento de uma aristocracia operária não somente através dos superlucros auferidos pela sobrexploração imperialista, mas também quando determinado setor econômico ou indústria consegue elevar seus ganhos por cima da taxa média de lucro de uma determinada sociedade, utilizando-se politicamente estes estratos "aristocratizados" contra o restante da classe trabalhadora.
} 


\section{Trabalhonecessário}

ISSN: 1808 - 799X

ANO 12, № 19 - 2014

requisições do mercado concorrencial, com seus critérios capitalistas de lucro e rentabilidade, fato que empurra as cooperativas a adequarem-se às normas vigentes de exploração da força de trabalho, impondo ritmos de produtividade, salários e jornadas semelhantes às praticadas pelas demais empresas capitalistas $^{13}$.

Além disso, Luxemburgo ([1900], 2012) lança mão de outro argumento importante para contestar a capacidade do cooperativismo engendrar transformações substanciais na ordem social capitalista: os principais setores da economia (sobretudo indústrias de base, como por exemplo, a produção de petróleo, ferro e aço) encontrar-se-iam monopolizados pelos grandes trustes capitalistas, vedando a penetração do cooperativismo nestes setores. O que fatalmente empurra tais cooperativas para os ramos menos importantes da economia como um todo, se alojando principalmente nos setores de produção de bens de consumo não duráveis e de gêneros de primeira necessidade, como alimentos e vestuário $^{14}$.

Em resumo, Luxemburgo ([1900], 2012) polemiza com a socialdemocracia reformista. Confronta a "aristocracia operária" que começa a se constituir nestas primeiras décadas de capitalismo monopolista, por conta das inovações advindas do fordismo e do imperialismo, que estendem os direitos políticos e sociais para o operariado dos países capitalistas centrais. Nestas condições, Luxemburgo pre -

\footnotetext{
${ }^{13}$ Quase um século depois, os mesmos argumentos são empregados por Alves e Tavares (2006), quando criticam a pseudo autonomia atribuída aos empreendimentos econômicos solidários em meio a uma sociedade capitalista como a nossa.

${ }^{14}$ Curioso como a mesma problemática ressurge hoje, frente ao novo cooperativismo fomentado pela Economia solidária, através da discussão em torno da necessidade de formar "cadeias econômicas solidárias", tal qual defendida por Mance (2003), visando evitar ou minorar a dependência em relação às indústrias capitalistas que são produtoras de matérias-primas empregadas pelas cooperativas ou simplesmente consumidoras da produção cooperativada. Mance (2003) e outros estudiosos perceberam a possibilidade dos empreendimentos econômicos solidários serem explorados e fornecerem sobretrabalho a tais indústrias.
} 


\section{Trabalhonecessário}

ISSN: 1808 - 799X

ANO 12, № 19 - 2014

cisa levar em frente o combate da viragem conservadora que ameaçava a caminhada do proletariado rumo à construção do socialismo ${ }^{15}$.

Outra polêmica será travada com o pensamento leninista e o bolchevismo russo. O pensamento da revolucionária alemã se afastará não só daqueles caminhos propugnados pela ala reformista da socialdemocracia, como também confrontará (em parte) os métodos vitoriosos defendidos por Lênin e pelos bolcheviques russos.

Em "Greve de massas, partidos e sindicatos", produzido no ano de 1906, a partir da observação dos acontecimentos revolucionários ocorridos na Rússia em 1905, a pensadora enfoca a questão da greve geral enquanto instrumento da luta revolucionária contra o capital. Naquela época, essa discussão estava muito em voga no interior do movimento operário (LUXEMBURGO,[1906], 2003). Ao discutir a questão da greve geral, Luxemburgo ([1906], 2003) acaba tocando no tema do papel do partido revolucionário e dos sindicatos dentro da mesma dinâmica. Assim sendo, começa a expor a sua própria concepção de luta de massas, de novo polemizando com outras correntes político-ideológica então atuantes no movimento operário (a tradicional socialdemocracia, 0 anarquismo e o bolchevismo).

Luxemburgo ([1906], 2003) vai se contrapor, fundamentalmente, à ideia de que o instrumento da greve geral seja "uma navalha", carregada na "bolsa" do movimento, para ser empregada assim que as direções partidárias, em conjunto com os sindicatos, julgassem conveniente. Para Luxemburgo ([1906], 2003), a chamada "greve de massas" seria resultado de uma série de fatores (políticos, e-

\footnotetext{
15 Aqui se faz oportuno lembrar algo importante sublinhado por Tragtenberg (1989): o Partido Comunista alemão e o Partido Socialdemocrata do mesmo país passaram a rivalizar e disputar a hegemonia sobre a classe trabalhadora daquele país. É dentro deste quadro que devemos compreender a batalha política e teórica travada por Rosa Luxemburgo contra a tendência reformista.
} 


\section{Trabalhonecessário}

ISSN: 1808 - 799X

ANO 12, № 19 - 2014

conômicos, culturais, históricos e até psicossociais) e a ação da vanguarda revolucionária seria somente um, dentre muitos.

Logo, do ponto de vista de Luxemburgo, direções partidárias e sindicais não seriam capazes de, por si só, levarem a cabo uma bem sucedida greve geral. A ação efetiva, espontânea e autônoma das massas populares, teria, necessariamente, o papel principal neste processo. Com efeito, Luxemburgo ([1906], 2003) conclama todos os interessados à observação dos fatos ocorridos na Rússia, um ano antes (em 1905), a fim de corroborar a sua tese. Para ela a história demonstra o conteúdo francamente espontâneo e revolucionário das greves russas, para as quais foi mínima a influência das direções partidárias em seu estopim.

Continuando, Rosa entende a greve de massas como sendo um produto de circunstâncias históricas, que fugiria ao absoluto controle das direções partidárias e sindicais (não significando isto que tais organizações não pudessem influenciar o curso dos acontecimentos). Diferente daquilo que comumente se imaginava na época, para Luxemburgo ([1906], 2003) as greves de massas constituíam indícios ou expressões de uma situação já revolucionária, ao contrário das teses que atribuíam a tarefa de "criar" uma situação revolucionária a partir das citadas greves.

Nestes termos, caberia ao partido revolucionário tirar o melhor proveito possível da situação, propagando seus ideais e sabendo, oportunamente, traduzir as aspirações populares e orientá-las no sentido de uma real transformação revolucionária da sociedade. Já aqui, pelos idos do ano de 1906, Luxemburgo ([1906], 2003) defenderá uma idéia que será recorrente em seu pensamento, a saber: a preocupação intransigente com a garantia do protagonismo das massas em todo o processo de construção socialista. Ainda que aceite a importância e a necessidade do partido revolucionário, o pensamento da revolucionária alemã re- 


\section{Trabalhonecessário}

ISSN: 1808 - 799X

ANO 12, № 19 - 2014

fletirá, a todo instante, a preocupação com a possibilidade de o partido dirigente açambarcar o protagonismo popular e, consequentemente, erigir novos dirigentes da sociedade, bloqueando o caminho da emancipação dos trabalhadores.

\section{2- A organização socioeconômica da nova sociedade socialista segundo Rosa Luxemburgo.}

Luxemburgo ([1917], 1991), mesmo reconhecendo os inegáveis méritos da revolução, aponta fatos ou iniciativas que, no seu entender, significaram equívocos na edificação do socialismo na Rússia. Aqui abordaremos alguns eixos importantes do pensamento de Luxemburgo para estabelecer um panorama da sua visão da nova sociedade autogerida. Neste ponto é importante tratar da questão da reorganização da agricultura sobre novas bases socialistas; a questão da autodeterminação de povos e etnias vizinhas à Rússia revolucionária; e, por fim, o lugar ocupado pela participação política e pelas liberdades democráticas na construção de uma sociedade socialista.

Para começar, vejam sua apreciação da iniciativa do governo revolucionário que incitou ou convocou o campesinato russo à repartição das terras da reacionária aristocracia rural, através de comitês agrícolas. Luxemburgo considera que tal reforma agrária terminou sendo um retrocesso ou um empecilho criado para posterior supressão da propriedade privada no campo e socialização da produção agrícola. A partir da reforma posta em prática pelos bolcheviques, formou-se na Rússia um enorme campesinato que, a partir de então, defendeu sua propriedade recém-conquistada a todo custo, opondo-se a quaisquer tentativas de coletivização.

Luxemburgo argumentava que era mais fácil expropriar uma relativamente pequena e abatida aristocracia fundiária do que um contingente imenso de camponeses fortalecidos com as conquistas revolucionárias. Assim, a repartição 


\section{Trabalhonecessário}

ISSN: 1808 - 799X

ANO 12, № 19 - 2014

das terras entre os camponeses, propugnada pelos bolcheviques no poder, trouxe enquanto consequência não só a manutenção da propriedade privada em grande parte da Rússia que era agrária, como também beneficiou a burguesia rural e os camponeses ricos. Essa elite econômica soube conquistar as maiores vantagens na repartição das terras promovida pelos comitês agrícolas. O que, no limite, significou o aumento da desigualdade social no campo (LUXEMBURGO, [1917] 1991).

Quanto à indústria e demais atividades econômicas urbanas, Luxemburgo ([1917], 1991) defendeu a substituição do trabalho assalariado e da dominação de classe pelo trabalho cooperativo. "Os meios de trabalho não devem mais ser monopólio de uma classe, mas tornar-se bem comum (...) Regulamentação da produção e repartição dos produtos no interesse da coletividade"

(LUXEMBURGO, [1917], 1991, p.101).

No que diz respeito exatamente à socialização dos meios de produção, Luxemburgo ([1917], 1991) sustentará que tal feito revolucionário não poderia ser fruto de decretos e leis. Mas, sobretudo, realizado na prática pela imensidão de trabalhadores e trabalhadoras, através de comissões de fábrica e de outras formas representativas no interior do próprio processo produtivo. Além disso, Luxemburgo ([1917], 1991) afirmará também a necessidade de uma nova ordem no âmbito das empresas, livre de hierarquias, onde predomine a autonomia, o senso de responsabilidade para com o trabalho, sem a necessidade da constante vigilância de um contramestre.

Eleições, em todas as fábricas, de conselhos de fábrica que, de acordo com os conselhos operários, deverão administrar todos os assuntos internos da empresa, as condições de trabalho, controlar a produção e, finalmente, assumir a direção da empresa. (LUXEMBURGO, [1917] 1991, p.108). 


\title{
Trabalhonecessário
}

ISSN: 1808 - 799X

ANO 12, № 19 - 2014

\section{3- Rosa Luxemburgo e a organização sociopolítica da nova sociedade socialista.}

No que concerne à reorganização da nova sociedade, sob o ponto de vista sociopolítico, Luxemburgo ([1917] 1991) tem enquanto paradigma histórico a Comuna de Paris. Para ela, a espinha dorsal da nova ordem socialista e autogerida seriam os conselhos de operários e soldados. Estes estariam capacitados para escolherem representantes e enviá-los a um conselho central, tendo, necessariamente, os organismos de base o direito de revogar o mandato concedido a qualquer instante, caso estes não cumpram com as determinações acordadas pelas bases. Para Luxemburgo ([1917] 1991), os conselhos teriam papel de destaque na nova sociedade, permitindo a progressiva ocupação das funções públicas pelas massas.

Ademais, Luxemburgo ([1917] 1991) ressaltará com veemência a importância da manutenção das garantias e liberdades políticas das massas para o processo de construção do socialismo.

\begin{abstract}
O sistema social socialista não deve e nem pode ser senão um produto histórico, nascido da própria escola da experiência, nascido na hora da sua realização, resultando do fazer-se da história viva [...] O socialismo, por sua própria natureza, não pode ser outorgado nem introduzido por decreto. Ele pressupõe uma série de medidas coercitivas, contra a propriedade etc. Pode-se decretar o negativo, a destruição, mas não o positivo, a construção (LUXEMBURGO, [1917], 1991, p.92).
\end{abstract}

Neste aspecto, Luxemburgo ([1917], 1991) criticará Lênin e os bolcheviques por terem, de certa forma, asfixiado a vida pública, contribuindo para suprimir a participação democrática do povo. Nestes termos, Luxemburgo ([1917], 1991) destaca que a Rússia deixa de constituir uma assembleia nacional ou de empregar o sufrágio universal em quaisquer outras instâncias, dificulta as liberda- 


\section{Trabalhonecessário}

ISSN: 1808 - 799X

ANO 12, № 19 - 2014

des de imprensa, de reunião e associação. Para Luxemburgo, em que pese os argumentos que acusam as deficiências ou insuficiências de tais instituições democráticas, o grau de participação popular engendrado pela revolução seria capaz de "vivificar", oxigenar e dar vida constante, corrigindo possíveis deficiências dessas instituições.

Segundo Luxemburgo ([1917], 1991), a ditadura do proletariado diverge visceralmente da ditadura burguesa na medida em que a primeira necessita da maior educação e participação das massas. A construção do socialismo não seria uma "receita de bolo" de propriedade do partido, mas uma construção cotidiana das massas populares.

A esta altura, vale a pena pensar na questão levantada por Loureiro (1995), quando esta nega o equivocado rótulo atribuído a Luxemburgo, segundo o qual ela seria uma defensora a priori da "democracia" e das "liberdades democráticas". Em verdade, retifica Loureiro (1995), ela nunca foi uma defensora da "democracia como valor universal", mas acreditava na importância desta para a construção do socialismo e vice-versa. Ou seja, para que a democracia adquirisse cunho real, deixando de ser mera "fraseologia" oca como ocorre no capitalismo, no socialismo a democracia ganharia "carne e osso".

\footnotetext{
A essência da sociedade socialista consiste no seguinte: a grande massa trabalhadora deixa de ser uma massa governada, para viver ela mesma a vida política e econômica na sua totalidade, e para orientá-la por uma autodeterminação consciente e livre. (LUXEMBURGO, [1917], 1991, p.102).
}

Em suma, a participação das massas na construção da nova sociedade é crucial para Luxemburgo, seja no aspecto sociopolítico, seja no âmbito econômico. Essa é a preocupação que perpassa o conjunto da sua obra. 


\section{Trabalhonecessário}

ISSN: 1808 - 799X

ANO 12, № 19 - 2014

\section{4- Concluindo: autogestão, marca indelével do pensamento de Rosa Luxemburgo.}

A análise da concepção de autogestão no pensamento de Rosa Luxemburgo nos conduziu a uma conclusão importante: suas propostas acerca da autogestão tomaram por parâmetro as novas condições históricas proporcionadas pelo advento do imperialismo e pela primeira experiência de construção do socialismo no século XX, (a Revolução Russa de 1917).

Em seu clássico estudo sobre o imperialismo, Lênin ([1916], 2001) sublinhou exaustivamente que aquelas primeiras décadas do século passado exibiam uma transformação qualitativa no modo de produção capitalista. Mudanças que atingiam a totalidade da vida social, promovendo alterações nas condições sociais, políticas, econômicas e culturais ao redor de todo o planeta ${ }^{16}$. Sem desejar fazer uma minuciosa descrição do período histórico em questão, destacamos, em meio à gama de transformações engendradas pelo novo estágio monopolista e imperialista do capitalismo, aqueles aspectos mais determinantes para o presente trabalho.

Assim, nos termos acima propostos, destacamos a forte presença da chamada "aristocracia operária" no cenário político, social, econômico e ideológico, principalmente dos países centrais do sistema capitalista mundial. Esse era um traço fundamental nas formulações criticas de Rosa Luxemburgo. Conforme mencionado anteriormente, a formação de uma "aristocracia operária" fora produto da monopolização de setores inteiros da vida econômica de uma nação e da exploração imperialista. Isto, conjuntamente, permitia a burguesia o al-

\footnotetext{
16 Lembremos aqui da seguinte passagem contida em Marx:

"A burguesia não pode existir sem revolucionar permanentemente os instrumentos de produção, por conseguinte as relações de produção, por conseguinte todas as relações sociais. A conservação, sem alterações, do antigo modo de produção era, pelo contrário, a condição primeira de existência de todas as anteriores classes industriais. O permanente revolucionar da produção, o abalar ininterrupto de todas as condições sociais, a incerteza e o movimento eternos distinguem a época da burguesia de todas as outras..." (1982, p 109-110).
} 


\section{Trabalhonecessário}

ISSN: 1808 - 799X

ANO 12, № 19 - 2014

cance de "superlucros", ou seja, taxas de lucratividade acima da média obtida em setores ou firmas não monopolistas.

Logo, se torna impossível não reconhecer que a extensão de direitos políticos e sociais, bem como melhorias, relativas, nas condições de remuneração da força de trabalho em países como Alemanha, Inglaterra, França e Itália, basearam-se na superexploração do proletariado nos países subdesenvolvidos ou em igual sobrexploração de outros segmentos ou setores da classe trabalhadora nos países centrais.

Outro aspecto basilar na construção das propostas autogestionárias da autora abordada aqui foi a experiência da construção do primeiro Estado operário da história, a partir do advento da Revolução Russa de 1917. É conhecida e reconhecida a magnitude do prestigio que Lênin, enquanto principal líder daquela que seria a primeira revolução proletária da história, viria a alcançar perante o movimento operário internacional. Com relação a isto, Bihr (2010) reitera que a socialdemocracia e a vertente comunista leninista dividiram e competiram entre si pela hegemonia no movimento operário europeu da época. Logo, suas ideias adquiriram centralidade no período histórico em questão, bem como os caminhos seguidos pela Revolução Russa, sob o seu comando. Por conta disso, o pensador militante será alvo de criticas, apoios, propostas, ponderações...

As concepções autogestionárias de Rosa Luxemburgo e outros partiram dessa referência do pensamento leninista e da observação das ações práticas levadas a frente pelos bolcheviques, na Rússia atrasada.

Em síntese, Luxemburgo ([1906], 2003) criticava o excessivo "dirigismo" do partido leninista em sua própria organização interna e na sua relação com o movimento operário em geral. Além disso, se opunha também a uma série de medidas tomadas pelos bolcheviques no processo de consolidação do poder proletário na Rússia. Luxemburgo criticava Lênin em virtude deste subestimar a 


\section{Trabalhonecessário}

ISSN: 1808 - 799X

ANO 12, № 19 - 2014

capacidade espontânea ou autônoma das massas, impondo a tutela. Por outro lado, acreditava que a Revolução russa, embora sob o fogo cruzado da contrarrevolução imperialista mundial e face à traição do proletariado reformista dos países centrais (como a Alemanha), nunca deveria ter suprimido uma série de mecanismos de participação democrática. Na sua visão, a democracia proveria as massas populares da capacidade de tornar-se parte ativa e protagonista na construção do socialismo na Rússia.

Luxemburgo ([1917], 1991) compreendia e até aplaudia o heroísmo bolchevique na construção do poder proletário, porém discordava dos mesmos no que diz respeito às iniciativas voltadas para a manutenção da revolução. Para ela, a democracia com real participação popular seria o melhor caminho para a consolidação do poder recém-conquistado, perante o assédio do imperialismo e das forças reacionárias. Mecanismos como o sufrágio universal, os comitês, a assembléia constituinte e as liberdades públicas deveriam ser fomentadas, no sentido de possibilitar às massas a construção do socialismo. Com esta participação ativa, o proletariado estaria progressivamente sendo "preparado" para conduzir-se autonomamente, numa nova sociedade, livre de Estados e burocracias dirigentes.

Entretanto, apesar de todas as criticas, Luxemburgo ([1906], 2003) acentuava a indispensabilidade do partido revolucionário, porém não admitindo que este dirigisse as massas, ditando métodos de lutas e reivindicações. $O$ seu papel seria o de dar voz ou transformar as legítimas aspirações do proletariado num corpo coerente de reivindicações, numa explicita plataforma política voltada para a transformação social.

Tomando por exemplo o fenômeno da greve de massas, detidamente analisada, Luxemburgo ([1906], 2003) demonstra como as direções das burocracias sindicais e partidárias são relativamente incapazes de criar ou orde - 


\section{Trabalhonecessário}

ISSN: 1808 - 799X

ANO 12, № 19 - 2014

nar uma greve de massas, afirmando o conteúdo imprevisível e incontrolável de tais manifestações, que nada mais são do que a resultante de uma dada conjuntura revolucionária que se forma no seio das massas. Assim, na concepção de Luxemburgo, ao partido não caberia dar inicio ou fim a um movimento como este, mas apenas atuar, em meio à conjuntura, no sentido de traduzir as aspirações populares numa plataforma política acabada, voltada para a construção do poder popular.

Ademais, quanto à questão da autogestão no processo produtivo propriamente dito, Rosa Luxemburgo se mostra francamente favorável ao controle operário, ao contrário de Lênin. Em grande parte de seus escritos, o líder russo prima por uma organização heterogestionária do processo produtivo, inclusive chegando a tecer elogios ao modelo fordista que então despontava no mundo capitalista desenvolvido.

Em Rosa Luxemburgo, a autogestão do processo produtivo constitui, a um só tempo, meio e objetivo da revolução socialista. Compreende que nisto reside o aspecto essencial do socialismo, além de ser uma importante etapa na preparação do proletariado para assumir a direção do processo de produção. $O$ grau de socialização do processo produtivo levado a cabo sob a etapa monopolista do capitalismo somente viria a corroborar firmemente a ideia de que o papel exercido pelo capitalista no processo de trabalho era dispensável ${ }^{17}$.

Para Luxemburgo ([1917], 1991), a nova ordem sociopolítica deveria organizar-se em torno de uma estrutura conselhista, composta por uma miríade de conselhos de base que, por sua vez, dariam origem a um conselho central, compondo uma estrutura na qual o poder de fato emanaria das bases.

\footnotetext{
17 Lembremos as colocações de Engels (1983) sobre o avanço da socialização do processo de trabalho promovido pelo capitalismo pari passu a apropriação privada dos resultados do trabalho.
} 


\section{Trabalhonecessário}

ISSN: 1808 - 799X

ANO 12, № 19 - 2014

Assim, Luxemburgo ([1917], 1991) repete, à exaustão, a insubstituível necessidade da participação popular no complexo processo de edificação do socialismo, tarefa grandiosa para qual ninguém, nem qualquer partido de vanguarda, teria a fórmula pronta e acabada. Por isto, Luxemburgo ([1917], 1991) argumentará em favor do fomento à participação popular, já na etapa de transição ao socialismo, dando à democracia "efetivo conteúdo", seja através de mecanismos da democracia participativa, seja por intermédio da participação direta nos conselhos ou sovietes ${ }^{18}$.

\section{Referências}

ALVES, Maria Aparecida; TAVARES, Maria Augusta. A dupla face da informalidade do trabalho. "Autonomia" ou precarização. In: Ricardo Antunes (org.). Riqueza e miséria do trabalho no Brasil. São Paulo: Boitempo Editorial, 2006.

BIHR, Alain. Da grande noite à alternativa. O movimento operário europeu em crise, 2ª̂ed. São Paulo: Boitempo editorial. 2010.

BOURDET, Yvon e GUILLERM, Alain. Autogestão: uma mudança radical. Rio de Janeiro: Zahar Editores. 1976.

BRAVERMAN, Harry. Trabalho e capital monopolista. A degradação do trabalho no século XX. 3aㅡ ed. Rio de Janeiro: Editora Guanabara, 1977. BURAWOY, Michael. A transformação dos regimes fabris no capitalismo avançado. Revista brasileira de ciências sociais. №13, ano 5. Rio de Janeiro:Vértice/ANPOCS, 1990.

ENGELS, F. Do socialismo utópico ao socialismo científico. São Paulo: Global, 1983.

HOBSBAWM, Eric. Os trabalhadores. Estudos sobre a história do operariado. 2ª ed. São Paulo: Paz e Terra, 2000.

18 Loureiro (1995) ensina que no pensamento de Luxemburgo, democracia e socialismo são coisas interdependentes, interligados, sendo que um não sobreviveria sem o outro. Ainda de acordo com Loureiro (1995), a crítica de Luxemburgo à democracia burguesa reside na sua falta de conteúdo efetivo, no seu aspecto puramente formal mais do que real, traço que apenas as radicais transformações socialistas poderiam modificar dando real conteúdo à democracia. 


\section{Trabalhonecessário}

ISSN: 1808 - 799X

ANO 12, № 19 - 2014

A Era das revoluções. Europa 1789-1848, 10ª ed. 2005.

KOSIK, Karel. Dialética do concreto. 4ㄹed. Rio de Janeiro: Paz e Terra, 1976.

LÊNIN, V.I. O imperialismo, fase superior do capitalismo. São Paulo: Editora Centauro, [1916], 2001.

LOUREIRO, Isabel M.Rosa Luxemburgo. Os dilemas da ação revolucionária. São Paulo: Editora UNESP, 1995.

LUXEMBURGO, Rosa. A revolução russa. Petrópolis, Ed. Vozes, [1917] 1991.

$$
\text { .Reforma ou revolução? Disponível }
$$

em:<htttp://www.arquivomarxista.org/rosaluxemburgo [1900], (acesso em: Maio. 2012).

.Huelga de masas, partido y sindicato. Madri: Fundación Federico Engels, [1906], 2003.

MANCE, Euclides André. Redes de colaboração solidária. In: CATTANI, Antonio David (org). A outra economia. Porto Alegre: Veraz editores, 2003.

MARX, Karl. O CAPITAL. 4.ed. Lisboa: Editora Delfos, 1975.

MARX, Karl. O Capital. Cap. VI (inédito). Porto: Publicações Escorpião, 1977.

.O manifesto comunista In:

Obras escolhidas. Tomo I. Lisboa: edições Avante, 1982.

MARSHALL, T.H. Cidadania, classe social e status. Rio de janeiro: Zahar editores. 1968.

MÉSZÁROS, István. A teoria da alienação em Marx. São Paulo: Editora Boitempo, 2006.

NAHAS, Valéria Guimarães. Autogestão. CATTANI, Antonio D; HOLZMAN, Lorena (Orgs). Dicionário de trabalho e tecnologia. Porto Alegre: UFRGS Editora, 2011.

OFFE, C. Capitalismo desorganizado. 2ª ed. São Paulo: Brasiliense, 1995. QUINTANEIRO, Tânia; BARBOSA, Maria Lígia; OLIVEIRA, M. G. Um toque de clássicos: Marx, Durkheim e Weber. 2 ed. Belo Horizonte: Editora UFMG, 2002. TRAGTENBERG, Maurício. Reflexões sobre o socialismo. São Paulo: Moderna, 1989.

TROTSKY, L. A revolução traída (2007). Disponível em:<http://www.pco.org.br (acesso em: Maio. 2012). 